\title{
2 \\ Social Metabolism and Conflicts over Extractivism
}

\author{
Joan Martinez-Alier and Mariana Walter
}

\section{Introduction}

The natural resource conflict dimension of environmental governance is usually centred on the social and political aspects of production systems and has hardly addressed the biophysical features of the natural resources themselves. Here we aim to address renewable and non-renewable resource-extraction conflicts in Latin America in the context of a changing global social metabolism and increasing demands for environmental justice (M'Gonigle, 1999; Sneddon, Howarth and Norgaard, 2006; Gerber, Veuthey and Martínez-Alier, 2009; MartinezAlier et al., 2010). "Social metabolism" refers to the manner in which human societies organize their growing exchanges of energy and materials with the environment (Fischer-Kowalski, 1997; Martinez-Alier, 2009). In this chapter we use a sociometabolic approach to examine the material flows (extraction, exports, imports) of Latin American economies and furthermore look into the socioenvironmental pressures and conflicts that they cause. Sociometabolic trends can be appraised using different and complementary indicators. For instance, the Human Appropriation of Net Primary Production (HANPP) measures to what extent human activities appropriate the biomass available each year for ecosystems (Haberl et al., 2007). Other examples are indicators that study virtual water flows, the energy return on investment (EROI) or a product life cycle. Each indicator provides information on different aspects of our economic performance.

In this chapter we will address the economy-wide material flow analysis (MFA) in more detail. The MFA is "a consistent compilation of the overall material inputs into national economies, the material accumulation within the economic system and the material outputs to other economies or to the environment" (EUROSTAT, 2001: 17). MFA aims 
to complement the system of national accounting with a compatible system of biophysical national accounts, using tonnes per year as the key unit of measurement. Such methodology provides a picture of the physical dimension of the economy, where the total turnover of energy and materials of the socioeconomic system can be analysed historically or cross-sectioned through the accounting of input flows (tonnes of biomass, fossil fuels, construction minerals, etc.) or output flows (tonnes of materials exported, waste or pollutant generated). Focusing on the input side by taking into account all materials that enter into the national economy allows for an acknowledgment of the physical dimension of foreign trade and can determine the amount of all outputs transferred to the environment (Gonzalez-Martinez and Schandl, 2008). While MFA presents some limitations regarding, for instance, the qualitative differences between materials (i.e. toxicity, environmental or social context of extraction), it offers a picture of the overall evolution of the pressures exerted by an economy to extract renewable and non-renewable resources.

A social metabolic approach acknowledges that inputs into the economy ultimately become outputs from the economy in the form of waste (except for the part that accumulates as a stock, as in buildings). The main output in volume from rich economies (apart from wastewater) is carbon dioxide from the burning of fossil fuels, the excessive production of which is a main source of climate change. Solid wastes produced by the economy are disposed of locally (in landfills or incinerators), or sometimes exported to distant regions or countries. All goods circulate through "commodity chains" (Raikes, Friis Jensen and Ponte, 2000 ) - that is, from cradle to grave or from point of extraction to waste disposal. Ecological distribution conflicts occur at different stages as peasant or tribal groups, national or multinational companies, national governments, local or international NGOs, and consumer groups are all stakeholders.

Economic change generally occurs for the benefit of some groups and at the expense of other existing or future groups (Hornborg, 2009). Externalities can be positive (like the free environmental services provided by a forest) or negative. Negative externalities are not seen here as market failures but rather as (provisional) cost-shifting successes (Kapp, 1950). Optimistic views regarding ecological modernization, the "dematerialization" of the economy (Stern, 2004), are confronted with the reality of increased inputs of energy and materials into the world economy, thereby increasing the production of waste and ecological distribution conflicts. 
Ecological distribution conflicts are struggles over the burdens of pollution or over the sacrifices made to extract resources, and they arise from inequalities of income and power (Martinez-Alier and $\mathrm{O}^{\prime}$ Connor, 1996; Douguet, O'Connor and Noel, 2008). The concept of ecological distributive conflicts is born of the intersection between the fields of ecological economics and political ecology, which links the emergence of environmental conflicts in the global South with the growth of the metabolism of societies in the global North (which includes parts of China). Political ecology focuses on the exercise of power in environmental conflicts. In other words, the question is: Who has the power to impose decisions on resource extraction, land use, pollution levels, biodiversity loss, and more importantly, who has the power to determine the procedures to impose such decisions (Martinez-Alier, 2001, 2002; Robbins, 2004)?

Ecological distribution conflicts emerge from the structural asymmetries in the burdens of pollution and in the access to natural resources that are grounded in unequal distributions of power and income, and in social inequalities of ethnicity, caste, social class and gender (MartínezAlier, 1997; Martinez-Alier et al., 2011). As processes of valuation surpass economic rationality in attempts to assign market prices and chrematistic costs to the environment, social actors mobilize for material and symbolic interests (of survival, identity, autonomy and quality of life), beyond strictly economic demands of property, means of production, employment, income distribution and development (Leff, 2003). Sometimes the local actors claim redistribution, leading to conflicts that are often part of, or lead to, larger struggles of gender, class, caste and ethnicity (Agarwal, 1994; Robbins, 2004). Hence the concept of "environmental justice" is important. It was born in the USA (Bullard, 1990) and it has gained growing acceptance in extractive industries, water use and waste-disposal conflicts all over the word (Urkidi and Walter, 2011). Not all conflicts are born from immediate metabolic needs. Demand for certain commodities such as gold arises in part from the search to have an investment outlet that furthermore allows for speculation. Other metals, such as copper, can also be stored and used as guarantees for speculative loans. The fact remains that both energy-carriers (coal, gas, oil) and metallic minerals are inputs for the industrial economy and that their use, in total, grows more or less in proportion to the growth of the economy.

In this chapter, we analyse the material flows of Latin American countries and their implications in terms of socioenvironmental conflict. First, we present an overview of recent material-flow studies 
conducted in this region. Second, we examine in further detail the socioenvironmental pressures exerted by the extraction of renewable and non-renewable materials. We propose a classification of extractive conflicts based on the commodity at stake. With this double approach we address the process of growing primarization of Latin American economies, its trends and some of its drivers, while simultaneously exploring the local pressures and conflicts that this process is fostering. At the macroeconomic level, we point to the paradox that the large physical exports are unable, or scarcely able, to finance the imports so that many countries are falling into commercial deficits.

\section{Latin American sociometabolic trends}

Different indicators can be used to analyse Latin American sociometabolic features and trends. Here we consider recent MFA studies conducted on Latin American economies and discuss their implications in terms of socioenvironmental pressures and injustices. MFAs have been conducted in most Organisation for Economic Co-operation and Development (OECD) countries, but only recently has research been conducted in the Latin American region and some of its countries in particular, such as Argentina (Perez-Manrique et al., 2013), Colombia and Ecuador (Russi et al., 2008; Vallejo, Pérez Rincón and Martinez-Alier, 2011; West and Schandl, 2013; Samaniego, Vallejo and Martinez-Alier, 2014). MFAs conducted on the overall region indicate that there was a four-fold increase in material flows between 1970 and 2008 for domestic consumption and also for exports. The Latin American economy has certainly not become "dematerialized" - one could compare such trends with other geographical regions, such as Europe, where the rate of increase in material extraction has been much lower, or with India, which has a lower rate of material extraction per capita than Latin America and which is not a net exporter in physical terms (Singh et al., 2012). Such physical indicators are useful for characterizing the economic structure of countries and regions.

Latin American economies, and particularly South American economies, have a persistent and increasing physical trade deficit (West and Schandl, 2013). The physical trade balance (PTB) is the difference between the number of tonnes of materials that are imported by an economy and the number of tonnes that are exported. The monetary trade balance (MTB) is the difference between how much is paid for the imports and how much is earned by exports in monetary terms. Exports in tonnes are larger than imports in tonnes, resulting in a 


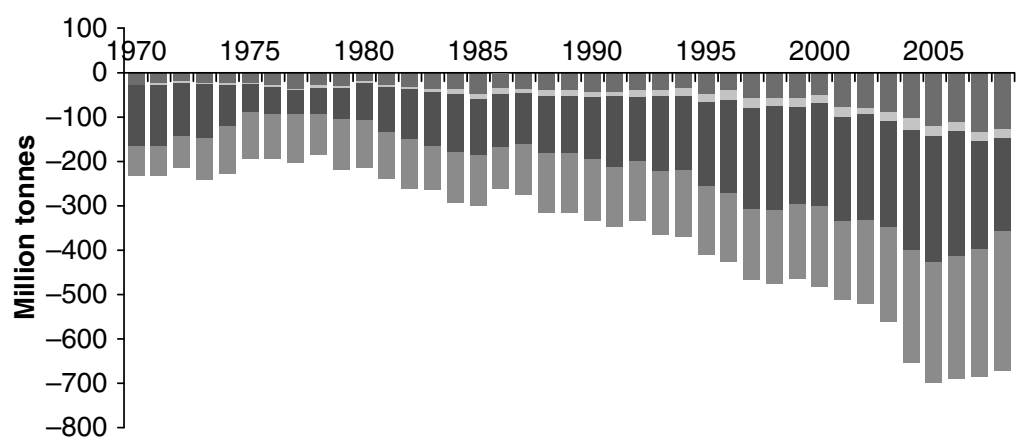

- Metal ores and industrial minerals $\quad$ Fossil fuels

Construction minerals Biomass

Figure 2.1 Latin America physical trade deficit in million tonnes, 1970-2008 Source: UNEP and CSIRO, 2013.

"deficit" in the same sense that would be applied to a tree plantation that grows less than the harvest rate. Figure 2.1 presents a yearly PTB of the Latin America region (including Mexico) per type of material from 1970 and 2008. Note in Figure 2.1 the increased physical trade deficit for metal ores and industrial minerals, which reflects the growing pressure to extract and export these materials. While one tonne of uranium is, of course, environmentally very different from one tonne of sand and gravel, or one tonne of cellulose from one tonne of shrimp, our aim here is to show trends within broad material categories, where the shift in the composition by commodities is not that important. Later we take a closer look at the different commodities within the categories of biomass and metal ores.

There are internal and external pressures to increase the extraction of materials, for domestic use and for export. Such increasing pressures to extract materials displace the commodity frontiers (Moore, 2000) to new territories often inhabited by peasant and indigenous groups, who complain accordingly as we signal in further detail in the next section (Conde and Walter, 2014). In regard to external trade, trends point to a structural persistence of an "ecologically unequal exchange". This concept challenges the argument that exports from developing nations foster economic growth and development, and points to the physical and socioenvironmental trade-offs at play (Hornborg, 1998; Muradian and Martinez-Alier, 2001; Bunker, 2007). Studies in this field highlight how poor countries are exporting goods at prices that do not take into 
account local externalities or depletion of natural resources, in exchange for the purchase of expensive goods and services from richer regions. One can measure ecologically unequal trade in terms of the inequality of various dimensions, such as hours of labour, hectares of land, tonnes of materials, water footprints, and joules or calories. When all or most indicators point in a similar direction, then we can state that there has been an unequal exchange (Hornborg, 2006). Ecologically unequal exchange arises from the structural fact that the metropolitan regions or countries require increasing amounts of energy and materials at cheap prices for their metabolism.

The terms of trade are persistently negative for South America as a whole and for most countries individually (one tonne of imports is always more expensive than one tonne of exports, from two to five times) in the very long term. However, the terms of trade improved somewhat in the first decade of the twenty-first century, fuelling a wave of optimism regarding economic growth but later deteriorating again (Samaniego, Vallejo and Martinez-Alier, 2014). Currently, the large physical exports can scarcely pay for the imports in most South American countries. A large physical trade deficit does not imply a positive MTB, and, on the contrary, recent LA trends point to simultaneous physical and monetary deficits. Either in 2013 or 2014, or in both years, there were commercial deficits in Brazil, Colombia, Ecuador, Peru and other countries. While Argentina's commercial surplus has been much reduced, there is now a need to finance commercial deficits (Samaniego, Vallejo and Martinez-Alier, 2014). For Argentina, our analysis of the external trade over a long period (1970-2009) shows (Figure 2.2) small monetary surpluses since the end of the 1990s (in 2001-2002 the surplus increased because the economic crisis violently reduced imports). Such small monetary surpluses almost disappeared in 2013-2014. From a physical point of view, Argentina has exported increasing amounts (in tonnes) since the early 1990s (between three and four times its imports in tonnes), thus demonstrating structurally negative terms of trade.

We do not enter into a detailed study here of the physical structure of external trade in the sense of looking at its biomass, mineral and fossil-fuel components (Perez-Manrique et al., 2013; West and Schandl, 2013). We point out, however, that Argentina exports - like Brazil large amounts of biomass. In comparison, another large South American country, Colombia, does not export large amounts of biomass products but it does export large amounts of coal. The PTB of Colombia shows long-term trends that are not very different from those of Argentina, 

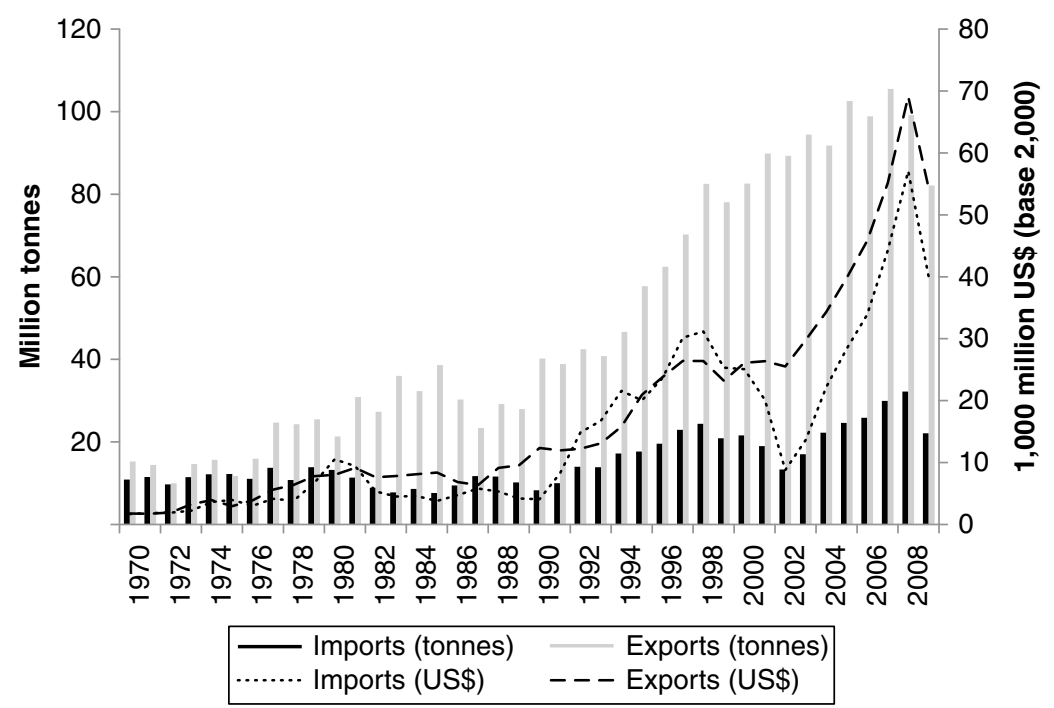

Figure 2.2 Argentina's physical and monetary external trade flows, 1970-2009 Source: Walter et al. (2013).

namely, physical exports exceed physical imports by a factor of no less than three (Figure 2.3). It must be noted that Colombia's large physical exports (which entail large unpaid socioenvironmental liabilities) are now unable to pay for the imports. As Figure 2.3 shows, in 2011, Colombia exported about 120 million tonnes and imported about 30 million tonnes, leaving a physical trade deficit of more than 90 million tonnes. This is for a country of more than 45 million inhabitants. Argentina, with a population of about 40 million, has reached exports of about 100 million tonnes and imports of about 30 million tonnes (Perez-Manrique et al., 2013). Similar trends, with slight differences, are identified in Brazil, Ecuador and Peru. Growing exports in tonnes (of different commodities) are not succeeding in improving the MTBs due to the negative terms of trade (Vallejo, Pérez Rincón and Martinez-Alier, 2011; Pérez-Rincón, 2014; Samaniego, Vallejo and Martinez-Alier, 2014).

To conclude this section, the critiques against extractivism have a double economic foundation. Domestic extraction and exports increase as they are driven by internal and external demand. Raw materialsbased economies incur disproportionate environmental costs, which are not factored into the price of commodities (Rice, 2007; Jorgenson, 2009; Roberts and Parks, 2009). Moreover, exhaustion of resources is 


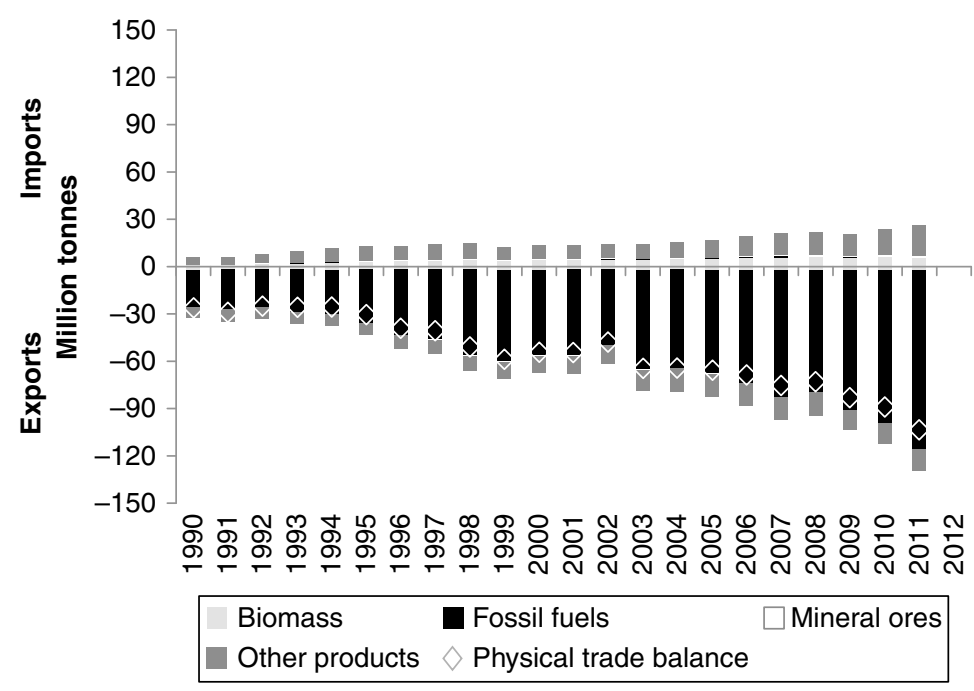

Figure 2.3 Physical trade balance of Colombia, 1990-2011 Source: Samaniego et al. (2014) based on COMTRADE, DANE.

renamed as "production" and it sustains periodic periods of bonanza. Outside demand does increase because of the metabolic needs of the world industrial economy. The recent growth of Asian economies, and China in particular, is exacerbating the primarization of Latin American economies by boosting the pressure to extract environmentally sensitive resources (Muradian, Walter and Martinez-Alier, 2012). Recently, an absurd situation has been reached: not only are the environmental costs of the booming extractive activities not accounted for, and the exhausted resources not replenished, but, moreover, the great excess of physical exports over imports is not able to pay for the imports. The commercial deficits will have to be compensated for by foreign investments or other forms of debt, which in due course will produce repayments to foreign countries. These are becoming key drivers that strengthen extraction trends, thereby expanding the commodity frontiers and reaching areas of high biodiversity and cultural value - the land of indigenous and peasant communities.

\section{Extractive conflicts in Latin America}

As pointed out in the previous section, there is an ongoing boom in the extraction of commodities in Latin America, and a large share of 
these materials is exported. This boom has been related to an increase in the number of extractive conflicts, which we frame as "ecological distribution conflicts". In order to elucidate the connections between sociometabolic trends and extractive conflicts, we propose a typology based on the commodity at stake. For each commodity type we will briefly explain some key features and illustrate with examples. Each commodity has its particularities and, as a result, different typologies could be proposed. We don't claim that the one used here is the best or the only possible one, but we use it as a guiding tool to distinguish key trends and features. We propose a classification that distinguishes between biomass (crops, plantations, fisheries) and minerals (metal ores, fuels, industrial, construction materials).

Within this typology, other subclassifications could be considered. For instance, from a social metabolism point of view, another distinction can be made between precious materials and bulk commodities when considering metallic minerals or biomass products (Wallerstein, 1974). Precious materials, such as diamonds, gold or shrimp, have a high economic value per unit of weight but are physically not necessary as inputs for the metabolism of the importing countries, compared with "bulk commodities", such as oil, gas, copper, iron, wood or soyabeans. This distinction does not mean that gold does not play an important social and economic role in the world of jewellery-making, in the world of love and marriage (as in India) or in the world of financial investments (Ali, 2006), but the difference stands in the point of view of the metabolism of the importing economies. Moreover, this difference is also related to different drivers for extraction and the related socioenvironmental pressure exerted.

\section{Biomass}

Extractive conflicts related to biomass involve a range of activities, including soy, oil palm and timber production, plantations, fisheries, and mangrove destruction and other deforestation. We could also include related conflicts such as those over the use of glyphosate (for the production of genetically modified organisms, such as soy) and over the implementation of projects for Reducing Emissions from Deforestation and Forest Degradation (REDD).

Let us consider here the case of Argentina (Perez-Manrique et al., 2013). As shown in Figure 2.4, biomass is the predominant material flow of this economy. On average, biomass represents $70 \%$ of all materials extracted in the country from 1970 to 2009, of which $71 \%$ comprise fodder for livestock (forage, silage, grazing and by-products), 


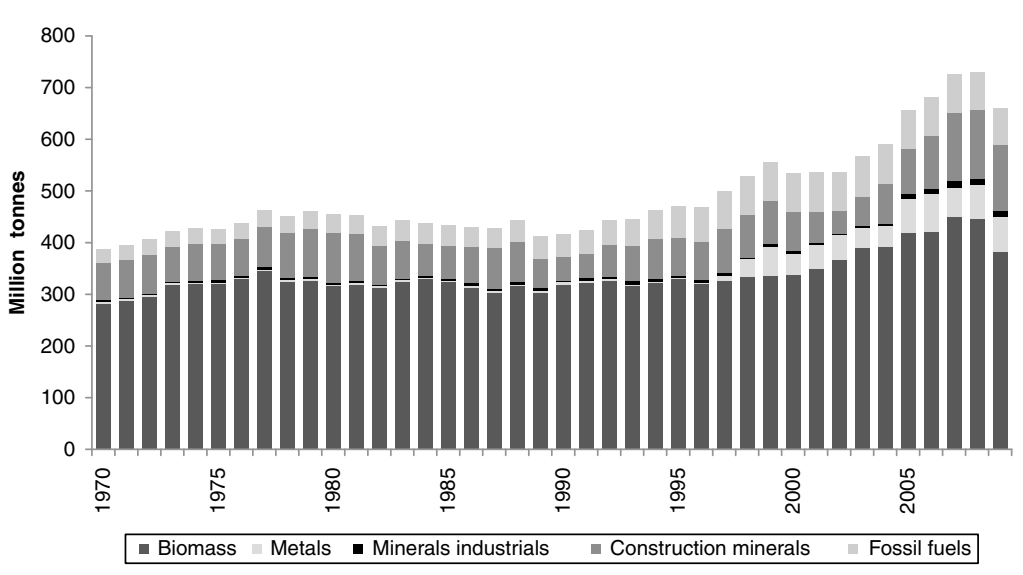

Figure 2.4 Domestic extraction in Argentina, 1970-2009 Source: Walter et al. (2013).

2\% fishing and forestry biomass, and 27\% crops. From 1997 to 2009, biomass extraction from primary crops increased from 50 megatonnes (Mt (1 million tonnes)) to $137 \mathrm{Mt}$, mainly for export. Soyabeans constitute the predominant flow within the primary crops. According to Pengue (2001), soyabeans (mostly genetically modified) have displaced other domestically produced crops such as cereals, roots, tubers, vegetables and melons. Indeed, during the period studied, these crops have decreased their participation in the primary crop extraction from $44 \%$ to $25 \%$ for cereals, from $6 \%$ to $2 \%$ for roots and tubers, and from $5 \%$ to $2 \%$ for vegetables and melons. From 1970 to 2009, Argentina's soyabean production jumped from 26,000 tonnes to $30.9 \mathrm{Mt}$. This growth was driven by high international prices for this commodity from the 1990s onwards, and by technological factors such as the mechanization of agriculture, and the introduction of transgenic soyabeans and chemical weeding with glyphosate (Teubal, 2006). Since the introduction of genetically modified soyabeans in Argentina in 1996, this crop represents an average of $26 \%$ of all primary crops.

The rise in crop production led to the expansion of the agricultural frontier, thereby clearing land and forest as well as displacing indigenous and rural communities. Since the 1990s, Argentina has been experiencing one of the largest processes of deforestation in the history of the country (UMSEF, 2007). This entails new issues, such as the weakening of food security, as crops are mainly exported and the production of locally consumed crops is decreasing. The growing use of agrochemicals 
produces water, air and soil pollution, and causes health impacts on the surrounding populations (Binimelis, Pengue and Monterroso, 2009). The harvested area of soyabeans multiplied from 38,000 hectares (Ha) in 1970 to 18 million $\mathrm{Ha}$ in 2009, accounting for more than half of the total agricultural land (MAGyP, 2011). The predominant biomass flow in the economy of Argentina is still grazing, foraging, silage and by-products. Nevertheless, the expansion of soyabean crops diminished the amount of land available for cattle-grazing. Millions of hectares that were in agricultural-cattle rotation have been allocated to permanent agriculture, while livestock increasingly depends on feed crops (i.e. cereal, soymeal) (Santarcángelo and Fal, 2009; PEA, 2010).

These trends have contributed to an increased number of conflicts over land in Argentina, as peasants and indigenous groups are confronted with the expansion of the soy-extraction frontier into their lands (Aranda, 2010). The expansion of the agricultural frontier has led to the clearing of lands and forest, as well as the displacement of many indigenous and rural populations (Teubal, 2006). This has resulted in various conflicts over access to land. This is the case for the inhabitants of La Primavera (Formosa, Argentina), who have been displaced by the expansion of soy production ever since 2008. Indigenous communities have been dispossessed of their lands, and the Qom people are struggling to recover 5,000 Ha (Asociación Civil Nodo Tau, 2010; García-López and Arizpe, 2010).

The increased use of chemicals in genetically modified (GM) crops has also triggered an increasing number of conflicts related to the health impacts. This is the case for the "mothers of Ituzaingó" of Cordoba, who lead a movement that is mainly composed of women who since 2001 have been demanding that the provincial government stop the air fumigation of soy fields. The spraying of large amounts of glyphosate near urban areas was causing cases of cancer (mostly in children) and birth defects induced by contamination. In 2009 the movement succeeded in forbidding the spraying of this product in urban areas (GRR, 2009). Incidentally, some invasive species such as Aleppo sorghum (or Johnsson grass) acquired resistance to glyphosate spraying, and as a result agriculture steps not only into a pesticide treadmill but also into a "transgenic treadmill" (Binimelis, Pengue and Monterroso, 2009).

Tree plantations have similarly been the subject of socioenvironmental conflicts. As analysed by Gerber (2011), industrial tree plantations for wood, palm oil and rubber production are among the fastest-growing monocultures and are currently being promoted as carbon sinks and energy producers. Such plantations are causing a large number of 
conflicts between companies and local populations, mostly in the tropics and subtropics. Relying on the most comprehensive literature review to date, corresponding to 58 worldwide conflict cases (drawing on the WRM database), Gerber (2011) finds that the prominent cause of resistance is related to corporate control over land that results in displacements and the end of local uses of ecosystems as they are replaced by monocultures.

Biomass conflicts related to fisheries and shrimp aquaculture are also relevant in Latin America. Let us briefly consider here the environmental injustices related to the promotion of the shrimp aquaculture industry in Central America, in the Gulf of Fonseca region of Nicaragua and Honduras on the Pacific Coast. This is one of the most densely populated areas in Central America and also one of the poorest. This regional economy depends, to a large extent, on artisanal fishing, specifically shellfish harvesting. Industrial aquaculture activities began in Honduras at the start of the 1970s and in Nicaragua in the second half of the 1980s with small-scale projects. Nowadays this activity has sharply increased. According to the Food and Agriculture Organization (FAO) of the United Nations, in 2008 production had reached 26,584 tonnes, and 14,690 tonnes in Honduras and Nicaragua, respectively. This implies an increase in total production of more than $200 \%$ in both countries over ten years (1998-2008). Most of the production is for export, mainly to the USA and to European markets. Where there were once estuaries and natural lagoons, nowadays there are large ponds for producing shrimp. In Nicaragua the surface area under production expanded from $771 \mathrm{Ha}$ in 1989 to $10,396 \mathrm{Ha}$ in 2009, and in Honduras from $750 \mathrm{Ha}$ in 1985 to 14,954 Ha in 2000 (Mestre Montserrat and Ortega Cerdà, 2012).

What was supposed to become a source of wealth for the regional economy has disempowered local fishing communities, which have seen their access to natural resources enclosed and limited. This has triggered serious social conflicts in the region. The industrial sites are located in areas populated by poor communities that rely on the communal use of coastal resources. The main response of the shrimp industry to the theft of their product has been the armed surveillance of their lands, both private and public. This has been a common practice in Nicaragua since 2008, when an agreement was established between the Association of Aquaculturalists of Nicaragua and the armed forces. These measures have further limited the access of local communities to coastal resources, fostering conflict and further impoverishing the population, thereby increasing social marginalization and unrest. As Mestre Montserrat and Ortega Cerdà (2012) indicate, successive conflicts 
between security forces protecting aquaculture farms and local fishermen have caused various injuries and at least one death in Nicaragua, and twelve deaths in Honduras. Fishermen have reported cases in which navigation to their fishing grounds through the estuarine channels has been restricted, along with cases of detention and harassment - in the form of constant demands for documentation to be shown - at sea. In Honduras, people engaged in campaigns to resist the expansion of the shrimp industry into protected areas have also been detained.

In Latin America, as elsewhere, the views of social groups involved in such conflicts over biomass are expressed in different "languages", using, for example, discourses about land and territorial dispossession, territorial rights, biopiracy, consultation rights, health impacts (due to chemical use), food sovereignty, human rights (given criminalization and militarization of extractive activities) and democracy. Unsustainable biomass extraction is also linked with conflicts over the rights of nature and of future generations, as biodiversity and nature's genetic pool are affected (by reducing the diversity of crops or advancing towards highdiversity areas). Potential future conflicts could also arise as intensive agricultural practices affect the long-term quality of soils (Pengue, 2001, 2004; Binimelis, Pengue and Monterroso, 2009).

\section{Minerals}

Mineral mining includes a range of commodities that can be grouped as metals (e.g. copper, gold, silver, iron, bauxite, uranium, nickel), mineral fuels (e.g. oil, gas, coal, shale oil), industrial minerals (e.g. phosphates, asbestos, salt) and construction minerals (e.g. sand, gravel, stones). The general stages of the mining process are shared: exploration to locate and characterize the mineral deposits, exploitation to mine the ores, mineral processing to refine the mineral, and transport to the consuming economies. However, the features and impacts of each commodity vary. Here we present some key features of the different minerals, and analyse in more detail metal and fuel minerals whose extraction is currently triggering significant debates in Latin America.

\section{Metal ores}

The extraction boom of raw materials in Latin American has been particularly significant for metal ores (see Figure 2.5). While in 1970 the weight of industrial and metal ores accounted for $10 \%$ of the total material flows of Latin America, in 2009 it reached 25\%. In fact, in 2009 , industrial and metals ores were, after biomass, the second greatest material extracted and, in part, exported from the region, accounting 


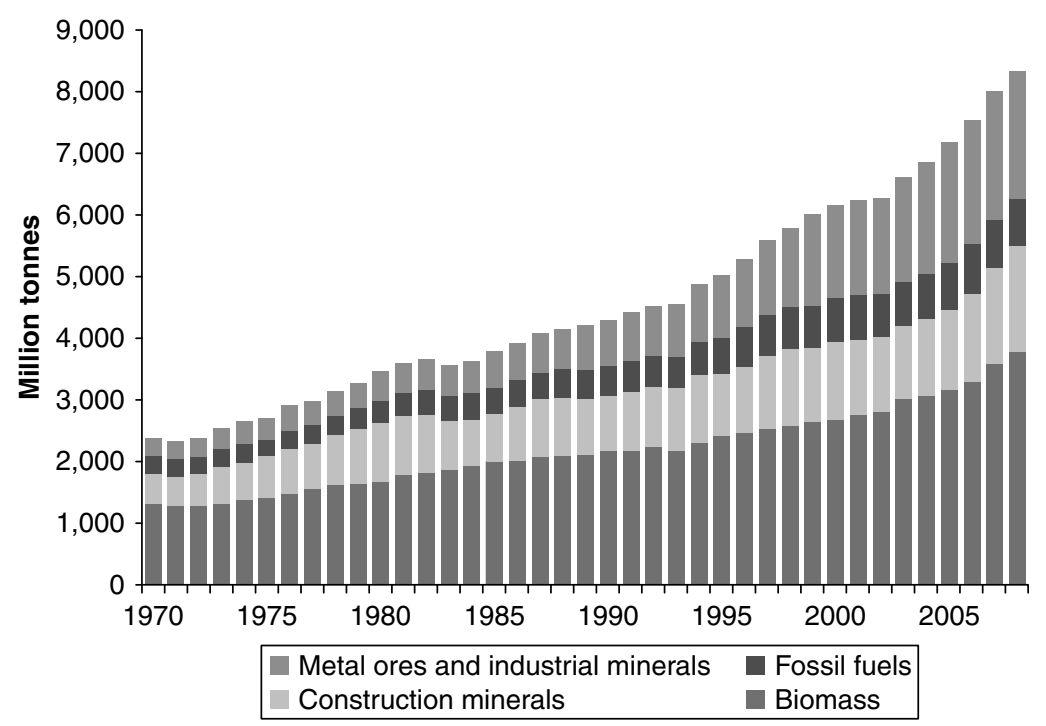

Figure 2.5 Domestic extraction in Latin America by major category of material, 1970-2008

Source: UNEP and CSIRO (2013).

for 2,100 million tonnes of ores (West and Schandl, 2013). In 2012, Latin America provided $45 \%$ of the global copper output, as well as $50 \%$ of silver, $26 \%$ of molybdenum, $21 \%$ of zinc and $20 \%$ of gold (Henriquez, 2012), attracting a third of global metal-mining investments (US\$210 billion) (Ericsson and Larsson, 2013). We will address with some detail metal ore extraction features and trends that are currently related to a boom of conflicts in Latin America.

One of the particularities of the metal-mining production chain is that its initial stages are characterized by low value but high environmental cost: resource extraction and then processing/refining have the highest impact. Later stages, such as assembling, are estimated to have less environmental impact but generate the majority of the economic value. This relationship represents a general trend of the impact/value curve that also applies more generally to other products that use metal ores (Giurco et al., 2010). Moreover, the socioenvironmental impacts of resource extraction increase when ore grades decline, as more waste is generated. As pressure to extract ores increases and the extraction frontier expands, reaching lower quality deposits, the environmental pressures in the stages of extraction and processing become greater (Giurco et al., 
Table 2.1 General conversion factors of gross ore versus metal content and ore concentrate

\begin{tabular}{lcc}
\hline Metal & Gross ore/metal content & Gross ore/concentrate \\
\hline Iron & 43.32 & 81.93 \\
Copper & 1.04 & 3.33 \\
Nickel & 1.83 & 23.45 \\
Lead & 11.86 & 16.52 \\
Zinc & 8.34 & 14.50 \\
Tin & 0.24 & 0.33 \\
Gold & 0.00021 & 0.06630 \\
Aluminium & 18.98 & 67.55 \\
Silver & 0.034 & 2.552 \\
Uranium & 0.0015 & 0.3744 \\
\hline
\end{tabular}

Source: Based on Schoer et al. (2012).

2010). Table 2.1 presents general conversion factors for the relationship between metal ores or concentrates and the gross ore that is mined. This factor is derived from the average of the annual business reports of about 160 metal mines in the world (Schoer et al., 2012).

Precious materials, such as gold, have the highest generation of overburden. As indicated in Table 2.1, to obtain 2 grams of gold, an average of 1 tonne of gross ore has to be mined. As the price per unit of precious metals is higher than for bulk metals, it becomes economically feasible to extract ore of decreasing quality or grade, entailing the processing of larger amounts of ore in open-cast mining and, as a result, generating increasing amounts of waste rock and tailings. This has also been made possible with the development of (more intensive) processing techniques that allow miners to obtain metals from decreasing ore concentrations (i.e. cyanide leaching for gold) (Bridge, 2004).

Moreover, other studies point to a worldwide decline in the quality of ore. ${ }^{1}$ As the high-grade ores have been depleted, the mining frontier moves to lower-grade ores, with increasing environmental costs. The decline in the quality of ores has direct implications in terms of land intervention of mining activities, as larger mines (open-pit mining) have to be built and larger quantities of waste rock - especially sensitive in the case of sulphidic material that has the potential to generate acid drainages ${ }^{2}$ - are generated (Bridge, 2004; Giurco et al., 2010; Mudd, 2010). For instance, recent studies conducted in the gold-mining sector in Australia indicate that, as ore quality decreases, the amount of water and energy used in the mining process increases significantly. 
This trend overlaps with other environmental pressures, such as larger requirements of chemical inputs and larger amounts of waste (Mudd, 2007a, 2007b; Giurco et al., 2010; Prior et al., 2012).

The significance of these trends grows as we consider the expansion of the mining frontier to sensitive and critical ecosystems, such as tropical and cloud forests, or the very high mountains next to pasturelands and glaciers. These are also the homes of indigenous people. As pointed out by Bridge (2004), an increasing proportion of mineral exploration and investment expenditures during the 1990s targeted the tropical areas around the globe, reaching ecologically sensitive and/or high-value conservation areas. The International Union for Conservation of Nature (IUCN) has raised concerns related to the expansion of the mining, gas and oil frontier in World Heritage Sites, demanding protection for them (IUCN, 2011). Furthermore, recent studies led by scholars and activists are pointing to the large overlap of mining concessions with the land of peasants and indigenous people in Latin America (Bebbington, 2012b). For instance, de Echave (2009, quoted in Bebbington, 2012b) estimates that over half of Peruvian peasant communities are affected by mining projects or concessions. According to the EJOLT database (see below), in Latin America, indigenous peoples are present in over 50\% of the environmental conflicts recorded to date in this registry (Pérez-Rincón, 2014). Chapter 11 on community consultations analyses in more detail some aspects of metal-mining conflicts in Latin America.

Moreover, it is important to stress that in the case of mining activities, ecoefficiency and technological approaches are limited. As the environmental impacts of mineral extraction can be reduced but not eliminated (Bridge, 2004), inputs to the mining process - such as water, energy or chemical compounds - can be reduced (per unit of production), the management of waste can be improved (e.g. better membranes to isolate waste from soil), and mining sites can be rehabilitated (e.g. revegetation). However, mineral mining necessarily modifies the environment to some degree. Moreover, operationalizing ecoefficiency in the mining sector is complicated by the fact that mining (unlike other industrial processes) is a segregative process that cannot avoid the production of large volumes of waste. This is increasingly significant considering the wider trends of declining ore qualities. Along the same vein, Giurco et al. (2010) maintain that mineral resource depletion is as much about falling resource quality (decreasing ores) and accessibility (distant and difficult to extract, with higher social and environmental costs and related conflicts) as it is about a reduction in resource quantity and availability. As follows, Prior and colleagues (2012) suggest that the "peak metal" 
(the time when extraction can no longer rise to meet the demand) has more to do with a carefully weighed decision that considers the social and environmental implications of continuing to extract than a question of existing metal quantities available.

In early 2014, OCMAL, a network of organizations that records largescale metal-mining conflicts, listed 203 active conflicts affecting 308 communities. According to OCMAL (2014), the largest number of mining conflicts are found in Peru (35), Chile (35), Argentina (26), Mexico (32), Brazil (20), Colombia (12), Bolivia (9) and Ecuador (7). Central America as a whole also has many mining conflicts. The impact of large-scale metal-mining activities on water, land, health, livelihoods and rights raises concerns among communities that feel disempowered by official decision-making procedures that place a premium on ecoefficiency and pecuniary criteria. Governments and mining companies frame complaints as being politically motivated and misinformed (Walter, 2014), but such a widespread wave of complaints (and so much violence against the protestors, at least in some countries) is evidence of a vigorous grassroots social movement.

\section{Mineral fuels}

This category includes a diversity of commodities, such as oil, natural gas and shale-gas fracking. We could also consider energy-related conflicts related to thermoelectricity plants. Oil is the main source of energy of modern societies; it is an essential input for the exosomatic energy metabolism of contemporary rich economies (transport, industry, etc.). The growth of the world economy has relied on fossil fuels over the last century, and the oil demand and consumption have increased steadily throughout the twentieth century. However, since the 1960s, there has been a decrease in the number of new discoveries of conventional oil reservoirs. Moreover, recent discoveries reveal decreasing quality, thus implying larger economic and environmental costs (Tsoskounoglou, Ayerides and Tritopoulou, 2008). As the pressure to find and extract conventional and unconventional fossil fuels augments, the frontiers of exploration and extraction expand, reaching environmental and socially sensitive locations.

One area in Latin America where the expansion of the oil-mining frontier has strongly impacted one of the culturally and biologically most diverse regions on Earth is in the Peruvian Amazon. Orta-Martínez and Finer (2010) indicate that since the 1920s, oil exploration and extraction in this region have threatened both biodiversity and indigenous peoples, particularly those living in voluntary isolation. They argue 
that the phenomenon of peak oil, combined with rising demand and consumption, is pushing oil extraction into the most remote corners of the world. As modern patterns of production and consumption, and high oil prices, are forcing a new oil exploratory boom in the Peruvian Amazon, conflicts are spreading across indigenous territories, new forms of resistance appear, and indigenous political organizations are born. The expanding oil and gas frontiers are overlapping with the lands of indigenous peoples, some of whom were previously uncontacted, which fosters conflict, disease and unrest among these communities (Finer and Orta-Martínez, 2010; Orta-Martínez and Finer, 2010; Gavaldà, 2013).

An important case of struggle over the environmental injustices of oil extraction is in Lago Agrio, in the Ecuadorian Amazon. Between 1964 and 1992, Texaco's oil operations polluted the northern region of the Amazon forest in Ecuador, spanning 1 million Ha inhabited by various indigenous communities and resulting in environmental and health damage. Texaco was bought by Chevron in 2001. In 1993, local residents and indigenous communities filed a class-action lawsuit against Texaco in the District Court in New York for damages caused to their health and to the environment. For ten years the case was stalled in the US Courts, until 2003, when eventually the trial was moved to the Ecuadorian Amazon town of Lago Agrio. In 2011, in a landmark judgement, the local Sucumbios court sentenced Chevron Texaco to pay US\$9.5 billion to the Frente de Defensa de la Amazonia, which would be doubled if the company did not publicly apologize. The court decision was upheld in 2012. Chevron has refused to pay and activists have tried to seize the company assets in third-party countries, such as Canada and Argentina.

\section{Industrial and construction minerals}

Industrial minerals include those used in industrial and agricultural processes. These minerals have different levels of toxicity and the pressures to extract them depend on their industrial uses. There are, for instance, conflicts related to the asbestos-mining in different places in Latin America. An example is the conflict of Sao Felix do Amianto in the state of Bahia (Brazil), which was open between 1939 and 1967 in the towns of Bom Jesus da Serra and Poçoes. There are many claims asking for compensation for health impacts, from workers both in the mine and in the factory.

There are also conflicts related to industrial minerals that are less toxic, such as phosphates. For instance, the Bayovar mine that is located in the north of Peru and is owned by Vale produces 5 million tonnes of phosphates per year (EJOLT, 2014). 
Construction minerals are materials such as sand and gravel that are related to urbanization processes and infrastructure construction. These materials travel less than other materials because of their relatively low price per unit of weight, and for this reason they tend to be near the sites of processing and final use. As follows, conflicts over quarries are usually related to conflicts over processing plants (e.g. cement factories). An example of conflicts related to sand and gravel extraction is in Rio Tunjuelo (Bogotá, Colombia), one of the main sources of construction minerals in Bogotá. Some 50 years of extraction of sands and gravels have changed the urban landscape, shaping large holes in the ground. These holes are 30, 50 or $70 \mathrm{~m}$ deep and have diameters that reach several hundreds of metres. In 2002, in order to avoid the impact of a serious flood, old mining holes were used as water reservoirs to divert overflowing water from the Tunjuelo River. Flooded quarries became a source of infections and bad odours, as abandoned quarries became water oxidation ponds. Social unrest was born from the impact of abandoned quarries on water, and the environmental impacts related to the nearby processing plants. Another example is the conflict in San Juan Sacatepequez in Guatemala, where indigenous communities fostered a local consultation to stop the opening of a quarry and its processing plant on their lands. These activities were promoted by the national government without the consent of local inhabitants (EJOLT, 2014).

\section{Conflicts at different points in the commodity chain}

The classification presented here focuses on extractive activities, but conflicts can emerge at other stages of the life cycle of a commodity. In such a way, material extraction is connected to environmental and social pressures at different localities and to social groups that exceed the specific place where extraction is occurring. We point to four key stages related to the life cycle of a (raw material) commodity where conflicts emerge: extraction, transport, processing and final disposal.

First, conflicts can arise at the site of extraction. We have previously pointed out some of the socioenvironmental pressures and conflicts directly related to extraction.

Second, the transport of raw materials to processing plants is also related to noise, dust and air pollution. This stage also includes the impacts and conflicts related to the construction of transport infrastructures, such as pipelines and ports. An example of the tensions related to these activities is the Initiative for the Integration of the Regional Infrastructure of South America (IIRSA), led by a group of Latin 
American governments with the support of the Interamerican Development Bank (IDB) and the Corporación Andina de Fomento (CAF). The IIRSA initiative aims to improve the connection of Latin American economies, connecting the Pacific and Atlantic oceans to facilitate the extraction and export of Latin American raw materials. It includes the construction of hydroways, gas and oil pipelines, ports and so forth. IIRSA-related projects are giving way to numerous large conflicts in the region (Svampa, 2012; Gavaldà, 2013), as these infrastructures are reaching the lands of distant communities that are also areas of high biodiversity and landscape value.

Third, processing plants usually require energy, water and chemical substances, and can also affect the quality of soil, air, and surface and underground waters, triggering health problems and social conflict. A paradigmatic case is La Oroya in Peru. La Oroya is a mining town in the Peruvian Andes that, since 1922, has been the site of a polymetallic smelter. This has produced toxic emissions and wastes from the plant. Recently the smelter was recycling scrap metals imported through El Callao (Lima's harbour) and taken up by railway to La Oroya, which has suffered from critical levels of air pollution and is considered to be one of the most polluted places on Earth (Blacksmith Institute, 2006). Owned by the Missouri-based Doe Run Corporation, the smelter was long signalled as responsible for the dangerously high lead levels found in children's blood.

Fourth, conflicts can arise when commodities reach the end of their life cycle and are discarded. Waste generation also includes impacts on soil, air and water generated during extraction, transport and processing (e.g. mining waste ponds and landfills). Climate change could be seen as a waste-disposal conflict because we have exceeded the capacity of new terrestrial vegetation and the oceans to absorb the carbon dioxide produced, and therefore its concentration in the atmosphere has increased to $402 \mathrm{ppm}$.

\section{New approaches to studying environmental conflicts: A statistical political ecology}

Since the 2000s, various groups have been creating online databases that register information on ongoing socioenvironmental conflicts in Latin America and beyond. These databases reflect an effort initiated by NGOs and social movements to make visible the increasing environmental injustices that communities confront. More recently, universities and research projects have also engaged in such systematization initiatives. 
Some aim at mapping out environmental conflicts in one country, such as a recent inventory of over 80 conflicts in Colombia (Pérez-Rincón, 2014) and the Brazilian Mapa da Injustiça Ambiental e Saúde (Environmental Injustice and Health Map, by FIOCRUZ). In addition, there is a growing number of databases recording socioenvironmental conflicts throughout the region, including OLCA, and worldwide, such as our EJOLT project (Martinez-Alier et al., 2011). There are also databases focused on specific issues, such as tree plantations (see WRM), mining (OCMAL) and land-grabbing (Genetic Resources Action International (GRAIN)). Furthermore, there are important efforts being made to report on processes of protest and "criminalization" of activists or human rights violations in Latin America and the Caribbean (OCMAL, 2013; Toledo, Garrido and Barrera Bassols, 2013). This "criminalization of protest" refers to different processes that range from government officials and politicians who promote and apply laws that typify protest as unacceptable social behaviour and label protest as sabotage, terrorism or an obstruction of public space; to protesting organizations as illicit associations or publicly framing protestors as criminals (Saavedra, 2013); and, most dramatically, to the reality of countries such as Brazil, Mexico, Colombia and Peru, where environmental activists are being killed while defending livelihoods and nature (see the lists provided by Global Witness). The ENGOV project has created an inventory of Latin American databases and maps (available at www.engov.eu), while the global inventory by EJOLT allows us to analyse and compare different features of numerous extractive conflicts (available at www.ejatlas.org).

\section{Conclusion}

In this chapter we have explained the main trends in the social metabolism of Latin America and have focused on one of the main indicators, the material flows. In the last 40 years the extraction of materials has increased four-fold, far more than the population. A substantial part of the extracted materials (whether biomass, fossil fuels or metal ores, although not the building materials) goes to exports. We have developed a typology of conflicts according to the commodities in question. Many grassroots environmental organizations, and also academics and state bodies, are aware that there are more ecological distribution conflicts, and they contribute to environmental governance by making them visible through inventories and maps.

In regard to external trade and economic policies, we have insisted that at present most South American economies have large physical 
trade deficits (in tonnes), and simultaneously they have or are about to have commercial trade deficits (in monetary terms). That is to say, the large physical exports that carry heavy ecological and social rucksacks are scarcely able to pay for the imports. In all of South America there are huge exports in volume (tonnes of oil, coal, iron ore, soyabeans, wood, copper, etc.) and yet several countries (Brazil, Colombia, Peru, Venezuela and Ecuador) have monetary commercial deficits. Remarkably, the recent "extractivist" trend happens both in countries with nationalpopular governments and in those with neoliberal governments. Even President Mujica of Uruguay favoured an iron-mining project with the Indian company Zamin Ferrous Metals in 2014. This project aims to export 18 million tonnes per year during the next 20 years - about 6 tonnes per inhabitant - leaving behind large environmental liabilities.

There are structurally unfavourable terms of trade for Latin American countries exporting natural resources. First, persistent physical trade deficits are recorded. We call it a "deficit" because natural resources are lost or depleted. In recent years, this trend has been accompanied by a monetary trade deficit that affects both small and large countries. Brazil had, between January and March of 2014, a trade deficit of US\$6,072 million. This is the highest deficit for a quarter in 21 years, while Argentina has seen its monetary trade surplus sharply decrease between 2012 and the first quarter of 2014. Monetary trade deficits must be balanced by other income in the current account or in the capital account balance. The inflow of foreign direct investment can offset the trade deficit but it will generate income that will later leave the country. Increased indebtedness will lead to a need to export more and more, causing further environmental damage and social conflict.

While the demand for raw materials that are not recycled (e.g. fossil fuels) or only partly recycled (e.g. metals) is likely to remain over time, even without economic growth in the world system, the social and environmental costs of extraction are increasing as the grade of metallic minerals and the EROI decreases. This is the case as oil or gas is extracted from distant places, as also happens with timber, soy or palm oil. At the same time, even if in the long term the demands remain, prices can fall sharply due to variations in the business cycles. Overall, reprimarization is a risky economic strategy. Therefore, it is not surprising that new Latin American voices call for different economic policies. For them, the local complaints against extractive industries (including biomass extraction) should not be seen as instances of NIMBY ("not in my backyard") or as attacks on the state, but instead as useful contributions towards a change in environmental governance. 
Therefore the criticism of South American post-extractivist scholars (Maristella Svampa, Eduardo Gudynas, Alberto Acosta) not only has a social and environmental basis but also has economic and democratic foundations. The export of raw materials depletes natural resources and causes pollution and conflicts with local populations. Governments use repression as a method to facilitate raw-material extraction. On the other hand, the prices of these major exports are cheap in comparison to imports, hence a new march along the route to debt. These tendencies point to the need for a change in policies. In fact, there have been some attempts to curb the export of raw materials through public policies such as the Yasuní-ITT initiative in Ecuador from 2007 to 2013, aimed at leaving oil in the ground under zones with exceptionally high biodiversity in the Ecuadorian Amazon. Popular resistance is also expressed in many existing protests, often arguing in terms of indigenous land rights. And new institutions arise as referenda or local consultations (see Chapter 11). These local protests and initiatives for environmental justice are a response to the power of corporations and governments, a power that leads to a deficit in local democracy. In sum, next to physical and monetary trade deficits, the export of raw materials also produces a deficit in local democracy.

\section{Acknowledgement}

We thank the journal Ecología Política journal and Julien Brun, Pedro Perez-Manrique and Ana C. Gonzalez-Martinez for granting us permission to use Figures 2.2 and 2.4.

\section{Notes}

1. A recent industry study signals that, "With declining ore grades exacerbated by increasing energy and other costs, and significant deposits being found at greater depths or in more remote areas, the average capital costs for copper production capacity in new mines increased an average of $15 \%$ per year over the past 20 years, with much of the increase evident since 2008" (SNL Metals Economics Group, 2013).

2. Mining-related chemical pollution can be generated by the release into the environment of reagents added during mineral processing, such as the sulphuric acid that is used for the leaching of copper oxides, or the mercury or cyanide used to process gold. Pollution is also caused by the oxidation that naturally occurs in minerals that are present in the ore as a result of exposure to air, water and/or bacteria. Many metal ores, such as nickel, copper and lead, occur in the rock as sulphides. The contact with oxygen and water triggers an oxidation process that forms sulphuric acid. This process can result in the formation of acid rock drainages. This process has been pointed out as one 
of the main environmental challenges of the mining industry (Bridge, 2004; Government of Australia, 2007; Giurco et al., 2010).

\section{References}

Agarwal, B. (1994) A Field of One's Own: Gender and Land Rights in South Asia (Cambridge: Cambridge University Press).

Ali, S.H. (2006) "Gold Mining and the Golden Rule: A Challenge for Producers and Consumers in Developing Countries", Journal of Cleaner Production 14(3-4): $455-462$.

Aranda, D. (2010) Argentina Originaria: Genocidios, Saqueos y Resistencias (Buenos Aires: La Vaca).

Asociación Civil Nodo Tau (2010) Asesinatos en Formosa: Indiferencia, Oídos Sordos y Represión, http://www.tau.org.ar/enredando2002-012/noticias_ desarrollo.shtml?x=62518, date accessed 12 January 2015.

Bebbington, A. (2012a) Social Conflict, Economic Development and the Extractive Industry: Evidence from South America (London and New York: Routledge).

Bebbington, A. (2012b) "Underground Political Ecologies: The Second Annual Lecture of the Cultural and Political Ecology Specialty Group of the Association of American Geographers", Geoforum 43(6): 1152-1162.

Binimelis, R., Pengue, W. and Monterroso, I. (2009) "Transgenic Treadmill: Responses to the Emergence and Spread of Glyphosate-Resistant Johnsongrass in Argentina", Geoforum 40(4): 623-633.

Blacksmith Institute (2006) The World's Worst Polluted Places. The Top Ten (New York: Blacksmith Institute).

Bridge, G. (2004) "Contested Terrain: Mining and the Environment", Annual Review of Environment and Resources 29(1): 205-259.

Bullard, R. (1990) Dumping in Dixie: Race, Class, and Environmental Quality (Boulder, CO: Westview Press).

Bunker, S. (2007) "The Poverty of Resource Extraction", in A. Hornborg, McNeil, J.R. and Martinez-Alier, J. (eds), Rethinking Environmental History: Worldsystem History and Global Environmental Change (Lanham, MD: Altamira Press), 239-258.

Conde, M. and Walter, M. (2014) "Commodity Frontiers", in G. D'Alisa, F. Demaria and G. Kallis (eds), Degrowth. A Vocabulary for a New Era (New York and London: Routledge), 71-74.

Douguet, J.M., O'Connor, M. and Noel, F. (2008) Systèmes de Valeur et Modes de Regulation: Vers Une Économie Politique Écologique (Paris: Cahiers du C3ED, UVSQ).

EJOLT (2014) Environmental Justice Atlas, http://elatlas.org, date accessed 16 January 2015.

Ericsson, M. and Larsson, V. (2013) "E\&MJ's Annual Survey of Global Mining Investment Project Survey 2013", E\&MJ Engineering and Mining Journal. http:// pure.ltu.se/portal/files/100685420/EMJ_2013.pdf

EUROSTAT (2001) "Economy-Wide Material Flow Accounts and Derived Indicators. A Methodological Guide", Luxembourg, Office for Official Publication of the European Communities. (Luxemburg: European Commission). 
Finer, M. and Orta-Martínez, M. (2010) "A Second Hydrocarbon Boom Threatens the Peruvian Amazon: Trends, Projections, and Policy Implications", Environmental Research Letters 5(1): 014012.

Fischer-Kowalski, M. (1997) "Society's Metabolism: On the Childhood and Adolescence of a Rising Conceptual Star", in M. Redcliff and G. Woodgate (eds), The International Handbook of Environmental Sociology (Cheltenham: Edgard Elgar), 119-137.

García-López, G.A. and Arizpe, N. (2010) "Participatory Processes in the Soy Conflicts in Paraguay and Argentina", Ecological Economics 70(2): 196-206.

Gavaldà, M. (2013) Gas Amazónico. Los Pueblos Indígenas frente al Avance de las Fronteras Extractivas en Perú (Barcelona: Icaria).

Gerber, J.F. (2011) "Conflicts over Industrial Tree Plantations in the South: Who, How and Why?", Global Environmental Change 21(1): 165-176.

Gerber, J.F., Veuthey, S. and Martínez-Alier, J. (2009) "Linking Political Ecology with Ecological Economics in Tree Plantation Conflicts in Cameroon and Ecuador", Ecological Economics 68(12): 2885-2889.

Giurco, D., Prior, T., Mudd, G., Mason, L. and Behrisch, J. (2010) Peak Minerals in Australia: A Review of Changing Impacts and Benefits (Sydney: University of Technology and Monash University).

Gonzalez-Martinez, A.C. and Schandl, H. (2008) "The Biophysical Perspective of a Middle Income Economy: Material Flows in Mexico", Ecological Economics 68(1-2): 317-327.

Government of Australia (2007) Managing Acid and Metalliferous Drainage. Leading practice sustainable development program for the mining industry. Department of Industry, Tourism and Resources. Canberra, Australia, http://www. industry.gov.au/resource/Documents/LPSDP/LPSDP-AcidHandbook.pdf

GRR (2009) "Pueblos Fumigados: Informe sobre la Problemática del Uso de Plaguicidas en las Principales Provincias Sojeras de La Argentina", Grupo de Reflexión Rural, http://www.grr.org.ar/trabajos/Pueblos_Fumigados_GRR_ .pdf, date accessed 3 December 2014.

Haberl, H. et al. (2007) "Quantifying and Mapping the Human Appropriation of Net Primary Production in Earth's Terrestrial Ecosystems", Proceedings of the National Academy of Sciences of the United States of America 104(31): 12942-12947.

Henriquez, V. (2012) "Latin America to Receive 50\% of Global Mining Investments Up to 2020", Business News Americas. http://www.bnamericas.com/ news/mining/latin-america-to-receive-half-of-global-mining-investment-until2020-codelco

Hornborg, A. (1998) "Commentary: Towards an Ecological Theory of Unequal Exchange: Articulating World System Theory and Ecological Economics", Ecological Economics 25(1): 127-136.

Hornborg, A. (2006) "Footprints in the Cotton Fields: The Industrial Revolution as Time-Space Appropriation and Environmental Load Displacement", Ecological Economics 59(1): 74-81.

Hornborg, A. (2009) "Zero-Sum World: Challenges in Conceptualizing Environmental Load Displacement and Ecologically Unequal Exchange in the World-System", International Journal of Comparative Sociology 50(3-4): 237-262.

IUCN (2011) "Mining Threats on the Rise in World Heritage Sites", International Union for Conservation of Nature. http://www.iucn.org/knowledge/news/?7742/ Mining-threats-on-the-rise-in-World-Heritage-sites 
Jorgenson, A.K. (2009) "The Sociology of Unequal Exchange in Ecological Context: A Panel Study of Lower-Income Countries, 1975-2000", Sociological Forum 24(1): 22-46.

Kapp, K.W. (1950) The Social Costs of Private Enterprise (Cambridge: Harvard University Press).

Leff, E. (2003) "La Ecología Política en América Latina, un Campo en Construcción", Polis 1(5): 1-15.

M'Gonigle, R.M. (1999) "Ecological Economics and Political Ecology: Towards a Necessary Synthesis", Ecological Economics 28: 11-26.

MAGyP (2011) "Sistema Integrado de Información Agropecuaria", Buenos Aires.

Martínez-Alier, J. (1997) "Conflictos de Distribución Ecológica", Revista Andina 29(1): 41-66.

Martinez-Alier, J. (2001) "Mining Conflicts, Environmental Justice, and Valuation", Journal of Hazardous Materials 86(1-3): 153-170.

Martinez-Alier, J. (2002) The Environmentalism of the Poor: A Study of Ecological Conflicts and Valuation (Delhi: Edward Elgar; Cheltenham: Oxford University Press).

Martinez-Alier, J. (2009) "Social Metabolism, Ecological Distribution Conflicts, and Languages of Valuation", Capitalism Nature Socialism 20(1): 58-87.

Martinez-Alier, J., Healy, H., Temper, L., Walter, M., Rodriguez-Labajos, B., Gerber, J. F. and Conde, M. (2011) "Between Science and Activism: Learning and Teaching Ecological Economics with Environmental Justice Organisations", Local Environment 16(1): 17-36.

Martinez-Alier, J., Kallis, G., Veuthey, S., Walter, M. and Temper, L. (2010) "Social Metabolism, Ecological Distribution Conflicts, and Valuation Languages", Ecological Economics 70(2): 153-158.

Martinez-Alier, J. and O'Connor, M. (1996) "Ecological and Economic Distribution Conflicts", in R. Costanza (ed.), Getting down the Earth: Practical Applications of Ecological Economics (Washington DC: Island Press), 277-286.

Moore, J.W. (2000) "Sugar and the Expansion of the Early Modern WorldEconomy: Commodity Frontiers, Ecological Transformation, and Industrialization", Review 23(3): 409-433.

Mudd, G.M. (2007a) "Global Trends in Gold Mining: Towards Quantifying Environmental and Resource Sustainability", Resources Policy 32(1-2): 42-56.

Mudd, G.M. (2007b) "Gold Mining in Australia: Linking Historical Trends and Environmental and Resource Sustainability", Environmental Science \& Policy 10: 629-644.

Mudd, G.M. (2010) "The Environmental Sustainability of Mining in Australia: Key Mega-Trends and Looming Constraints", Resources Policy 35(2): 98-115.

Muradian, R. and Martinez-Alier, J. (2001) "Trade and the Environment: From a 'Southern' Perspective", Ecological Economics 36(2): 281-297.

Muradian, R., Walter, M. and Martinez-Alier, J. (2012) "Hegemonic Transitions and Global Shifts in Social Metabolism: Implications for Resource-Rich Countries. Introduction to the Special Section", Global Environmental Change 22(3): 559-567.

Orta-Martínez, M. and Finer, M. (2010) "Oil Frontiers and Indigenous Resistance in the Peruvian Amazon", Ecological Economics 70(2): 207-218.

PEA (2010) "Plan Estratégico Agroalimentario y Agroindustrial Participativo y Federal 2010-2020". 
Pengue, W. (2001) The Impact of Soybean Expansion in Argentina, Seedling, http://www.grain.org/es/article/entries/292-the-impact-of-soybean-expansionin-argentina, date accessed 4 December 2014.

Pengue, W. (2004) "Producción Agroexportadora e (In)seguridad Alimentaria: El Caso de la Soja en Argentina", Revista Iberoamericana de Economía Ecológica 1: 46-55.

Perez-Manrique, P.L., Brun, J., González-Martínez, A.C., Walter, M. and MartínezAlier, J. (2013) "The Biophysical Performance of Argentina (1970-2009)", Journal of Industrial Ecology 17(4): 590-604.

Pérez-Rincón, M.A. (2014) Conflictos Ambientales en Colombia: Inventario, Caracterización y Análisis (Cali: Universidad del Valle, CINARA, EJOLT).

Prior, T., Mudd, G., Mason, L. and Behrisch, J. (2012) "Resource Depletion, Peak Minerals and the Implications for Sustainable Resource Management", Global Environmental Change 22(3): 577-587.

Raikes, P., Friis Jensen, M. and Ponte, S. (2000) "Global Commodity Chain Analysis and the French Filière Approach: Comparison and Critique", Economy and Society 29(3): 390-417.

Rice, J. (2007) "Ecological Unequal Exchange: International Trade and Uneven Utilization of Environmental Space in the World System", Social Forces 85(3): 1369-1392.

Robbins, P. (2004) Political Ecology: A Critical Introduction (London: Blackwell Publishing).

Roberts, J.T. and Parks, B.C. (2009) "Ecologically Unequal Exchange, Ecological Debt, and Climate Justice: The History and Implications of Three Related Ideas for a New Social Movement", International Journal of Comparative Sociology 50(3-4): 385-409.

Russi, D., Gonzalez-Martinez, A.C., Silva-Macher, J.C., Giljum, S., Martinez-Alier, J. and Vallejo, M.C. (2008) "Material Flows in Latin America. A Comparative Analysis of Chile, Ecuador, Mexico, and Peru, 1980-2000", Journal of Industrial Ecology 12(5-6): 704-720.

Samaniego, P., Vallejo, M.C. and Martinez-Alier, J. (2014) "Déficit Comercial y Déficit Físico en Sudamérica", Documento de Trabajo, Proyectos CSO201021979 e ENGOV, Institut de Ciència i Tecnologia Ambientals (ICTA), Universidad Autónoma de Barcelona, FLACSO Sede Ecuador.

Santarcángelo, J. and Fal, J. (2009) "Production and Profitability in Livestock in Argentina. 1980-2006", Mundo Agrario 10(19).

Schoer, K., Giegrich, J., Kovanda, J., Lauwigi, C., Liebich, A. Buyny, S. and Matthias, J. (2012) Conversion of European Product Flows into Raw Material Equivalents (Heidelberg: Ifeu; Eurostat).

Singh, S. J., Krausmann, F., Gingrich, S., Haberl, H., Erb, K.H., Lanz, P., Martinez-Alier, J. and Temper, L. (2012) "India's Biophysical Economy, 19612008. Sustainability in a National and Global Context", Ecological Economics 76-341(100): 60-69.

Sneddon, C., Howarth, R.B. and Norgaard, R.B. (2006) "Sustainable Development in a Post-Brundtland World", Ecological Economics 57(2): 253-268.

SNL Metals Economics Group (2013) "SNL Metals Economics Group's Copper Study Reveals Lower Grades, Higher Costs for Copper Production in 2012", PRWeb.

Stern, D.I. (2004) "The Rise and Fall of the Environmental Kuznets Curve", World Development 32(8): 1419-1439. 
Svampa, M. (2012) "Consenso de los Commodities, Giro Ecoterritorial y Pensamiento Crítico en América Latina", Observatorio Social de América Latina 32: $15-38$.

Teubal, M. (2006) "Expansión del Modelo Sojero en La Argentina. De la Producción de Alimentos a los Commodities", Realidad Económica 220: 71-96.

Tsoskounoglou, M., Ayerides, G. and Tritopoulou, E. (2008) "The End of Cheap Oil: Current Status and Prospects", Energy Policy 36(10): 3797-3806.

UMSEF (2007) Informe sobre Deforestación en Argentina (Buenos Aires).

UNEP and CSIRO (2013) Recent Trends in Material Flows and Resource Productivity in Latin America (Nairobi). http://www.unep.org/dewa/portals/67/pdf/ RecentTrendsLA.pdf

Urkidi, L. and Walter, M. (2011) "Dimensions of Environmental Justice in AntiGold Mining Movements in Latin America", Geoforum 42(6): 683-695.

Vallejo, M.C., Pérez-Rincón, M.A. and Martinez-Alier, J. (2011) "Metabolic Profile of the Colombian Economy from 1970 to 2007", Journal of Industrial Ecology 15(2): 245-267.

Wallerstein, I. (1974) The Modern World-System, Vol I.: Capitalist Agriculture and the Origins of the European World-Economy in the Sixteenth Century (New York and London: Academic Press).

Walter, M. (2014) Political Ecology of Mining Conflicts in Latin America (Barcelona: Autonomous University of Barcelona).

Walter, M., Brun, J., Perez-Manrique, P., Gonzalez-Martinez, A.C. and MartinezAlier, J. (2013). Análisis de flujo de materiales de la economía Argentina (19702009). Tendencias y Conflictos extractivos. Ecología Política 45: 94-98.

West, J. and Schandl, H. (2013) "Material Use and Material Efficiency in Latin America and the Caribbean", Ecological Economics 94: 19-27.

Except where otherwise noted, this work is licensed under a Creative Commons Attribution 3.0 Unported License. To view a copy of this license, visit http://creativecommons.org/licenses/by/3.0/ 